\title{
MODEL SENAM SI BUYUNG UNTUK PEMBELAJARAN MOTORIK KASAR PADA SISWA TAMAN KANAK-KANAK
}

\section{A GYMNASTIC MODEL SI BUYUNG AS A MEDIUM IN GROSS MOTOR LEARNING FOR KINDERGARTEN STUDENTS}

\author{
Galih Dwi Pradipta, Pamuji Sukoco \\ PPs UNY, Universitas Negeri Yogyakarta \\ galihdwipradipta@ymail.com, pamuji_sukoco@uny.ac.id
}

\begin{abstract}
Abstrak
Penelitian ini bertujuan untuk menghasilkan model senam Si Buyung untuk pembelajaran motorik kasar pada siswa TK. Senam Si Buyung yang dikembangkan diharapkan dapat digunakan guru TK sebagai salah satu bentuk pembelajaran motorik kasar pada siswa TK.Penelitian pengembangan ini dilakukan dengan langkah-langkah penelitian sebagai berikut: (1) pengumpulan informasi di lapangan, (2) melakukan analisis terhadap informasi yang telah dikumpulkan, (3) mengembangkan produk awal (draf model), (4) validasi ahli dan revisi, (5) uji coba lapangan skala kecil dan revisi, (6) uji coba lapangan skala besar dan revisi, dan (7) pembuatan produk final. Uji coba skala kecil dilakukan terhadap siswa kelas B dari TK Amal Mulia Mancasan yang berjumlah 15 anak. Uji coba skala besar dilakukan terhadap siswa kelas B dari TK Purbasari Dukuhsari Kalasan yang berjumlah 45 anak. Instrumen pengumpulan data yang digunakan yaitu; (1) angket, (2) lembar pedoman observasi senam Si Buyung, (3) lembar format penilaian anak. Teknik analisis data yang dilakukan yaitu analisis deskriptif kuantitatif dan analisis deskriptif kualitatif. Penelitian ini menghasilkan model senam Si Buyung untuk pembelajaran motorik kasar pada siswa taman kanak-kanak. Produk hasil penelitian pengembangan berupa buku RKH (Rencana Kegiatan Harian) dan video senam Si Buyung yang dibuat dalam bentuk CD. Dari hasil penilaian para ahli materi, dapat ditarik kesimpulan bahwa model senam Si Buyung yang dibuat layak digunakan untuk pembelajaran motorik kasar pada siswa TK.
\end{abstract}

Kata kunci: Senam Si Buyung, motorik kasar, dan anak TK.

\section{Abstract}

This research is aimed at developing a gymnastic model named Si Buyung as a medium in gross motor learning for kindergarten students. This gymnastic model is developed to help kindergarten teachers in conducting the teaching and learning of gross motor effectively and sufficiently. This educational research and development $(R \& D)$ was conducted by adapting $R \& D$ steps according to Borg \& Gall (1983, p.775), consisting of: (1) collecting information, (2) information analysis, (3) developing initial product, (4) expert validation and revision, (5) preliminary field test and revision, (6) main field test and revision, and (7) making the final product. The preliminary field test was conducted to 15 students Class B of TK Amal Mulia Mancasan and the main field test was conducted to 45 students Class B of TK Purbasari .Dukuhsari Kalasan Yogyakarta. Data collecting instrument used were: (1) questionnaire, (2) observation guide line in Si Buyung (3) scoring guide line for students' involvement in Si Buyung gymnastic. The data were analyzed using quantitative descriptive analyses and qualitative descriptive analyses.Based on the data and results of the study, it can be concluded that Si Buyung as a gymnastic model is appropriate and as a teaching and learning medium in gross motor learning for kindergarten students. The results of this study are in the forms of a book RKH (Rencana Kegiatan Harian) and Compact Disc (CD). Based on some judgements of the experts, it can be concluded that a gymnastic model Si Buyung developed is appropriate to be applied in the teaching of gross motor towards the students of kindergarten.

Keywords: Gymnastic Si Buyung, gross motor, and kindergarten students. 


\section{Pendahuluan}

Taman kanak-kanak adalah lembaga pendidikan prasekolah sebelum memasuki lembaga pendidikan sekolah dasar. Taman kanakkanak adalah suatu upaya pembinaan yang ditujukan kepada anak usia 4-6 tahun yang dilakukan melalui pemberian rangsangan pendidikan untuk membantu pertumbuhan dan perkembangan jasmani dan rohani agar anak memiliki kesiapan dalam memasuki pendidikan lebih lanjut. Di TK proses pembelajaran dalam perkembangan kemampuan dasar meliputi lingkup berbahasa, kognitif, dan fisik. Pembelajaran taman kanak-kanak mengembangkan aspek kognitif, afektif, dan psikomotor, untuk mencapai tujuan pembelajaran yang diinginkan guru dituntut untuk menggunakan cara yang kreatif. Salah satu cara yang digunakan guru dalam keberhasilan pembelajaran yaitu mampu menerapkan pembelajaran yang tepat untuk anak-anak di taman kanak-kanak.

Pembelajaran olahraga di TK bertujuan untuk meningkatkan perkembangan dan pertumbuhan anak, meningkatkan keterampilan dan ketangkasan, meningkatkan pengetahuan dan kecerdasan, serta menanamkan sikap-sikap positif pada anak. Mengajar olahraga di TK guru harus mempunyai model yang paling efektif dan efisien, karena jika model pembelajaran yang digunakan efektif dan efisien maka tujuan pembelajaran dapat tercapai. Guru diharapkan mampu memberikan pembelajaran yang atraktif dan menarik pada anak, sehingga tujuan-tujuan pembelajaran pada TK dapat tercapai. Tujuantujuan pembelajaran untuk meningkatkan keterampilan gerak dasar anak, misalnya untuk meningkatkan motorik kasar anak. Guru mampu memilih model pembelajaran yang tepat untuk menyusun materi-materi yang bertujuan untuk meningkatkan kemampuan motorik kasar anak. Guru mampu menggunakan model senam untuk pembelajaran motorik kasar di TK. Model pembelajaran senam di TK salah satunya adalah senam Si Buyung. Senam Si Buyung merupakan bentuk senam meniru yang sering digunakan dalam pembelajaran senam di TK. Senam Si Buyung dapat disusun dengan menggunakan lagu atau cerita, lagu dan cerita disusun supaya anak mampu meniru gerakan dalam senam Si Buyung.

Tujuan dari pembelajaran senam $\mathrm{Si}$ Buyung yaitu untuk meningkatkan kemampuan motorik kasar pada anak TK. Gerakangerakan yang disusun dalam senam Si Buyung mengacu pada SK dan KD, supaya gerakangerakan yang disusun layak digunakan untuk pembelajaran motorik kasar. Bentuk senam Si Buyung dapat berupa lagu atau cerita, dalam menyusun lagu dan cerita pada senam Si Buyung harus mengacu pada model tematik di TK. Konsep tematik di sini yaitu untuk memilih bentuk lagu atau tema cerita yang sesuai dengan karakteristik siswa. Guru dapat mengaplikasikan senam Si Buyung sebagai pembelajaran motorik kasar di TK, manfaatnya banyak dari menvariasikan model senam tersebut, selain untuk meningkatkan motorik kasar anak juga mampu melatih kognitif, afektif, dan psikomotor pada anak. Guru mampu kreatif dalam menyusun metode pembelajaran, sehingga anak tidak bosan dalam belajar. Anak senang dalam mengikuti pembelajaran maka materi-materi yang disampaikan guru akan mudah dipahami anak, sehingga tujuan pembelajaran yang diharapkan dapat tercapai.

\section{Senam Si Buyung}

Mawarti, dkk (2012, p.2) mendefinisikan senam Si Buyung adalah salah satu cabang dari senam ritmik yang di dalamnya ada unsur gerak dan irama, yang akan di tujukan untuk perkembangan sistem syaraf sensoris pada anak usia dini. Berdasarkan definisi tersebut senam Si Buyung ditujukan untuk anak usia dini, senam Si Buyung merupakan senam bentuk meniru melalui aktifitas gerak dan lagu. Bentuk dan isi senam Si Buyung dijelaskan sebagai berikut: (a) Senam Si Buyung bentuk cerita. Senam si Buyung yang di dalamnya terdapat unsur-unsur cerita sebagai media penarik anak didik untuk secara tidak sadar atau sadar melakukan gerakan yang diinginkan. Ketentuan: mulai dari awal sampai akhir ceritanya masih dalam satu tema. Di dalam cerita bisa dengan memfantasikan atau meniru gerakan tumbuhan, hewan, dan lain-lain; (b) Senam Si Buyung bentuk gerak lagu. Senam Si Buyung di mana di dalamnya terdapat unsur-unsur gerak lagu. Anak didik diharapkan mampu mengetahui bentuk tersebut dan mengevaluasi secara sederhana. Ketentuannya dari masing-masing gerak dalam sistematika senam harus dicocokkan dengan lagunya; (c) Isi latihan senam $\mathrm{Si} \mathrm{Bu}-$ yung: (A) pendahuluan/pema-nasan, (B) latihan inti: (B1) latihan tubuh (normalisasi), (B1.1) latihan penguluran, (B1.2) latihan pelemasan, (B1.3) latihan penguatan, (B1.4) latihan pelepasan, (B2) latihan keseimbangan, (B3) latihan kekuatan dan ketangkasan, (B4) jalan dan lari, 
(B5) lompat dan loncat, dan (C) pendinginan: penutup.

Metode mengajar senam Si Buyung berdasarkan urutannya yaitu latihan pemanasan/pendahuluan, latihan inti, dan latihan penenangan. Cara menyusun senam Si Buyung serta tujuannya antara lain sebagai berikut:

\section{Pemanasan}

Cara menyusun latihan pemanasan, (1) Bentuk gerakan menarik anak-anak serta menggembirakan, (2) Latihan pemanasan membuat semua anak bergerak, (3) Gerakannya tidak melelahkan untuk anak, (4) Bentuk gerakan mudah dimengerti dan dapat dilakukan semua anak dengan mudah.

Tujuan latihan pemanasan yaitu memenuhi hasrat bergerak anak, membawa/menyiapkan suhu badan anak kepada panas yang optimal guna menerima latihan selanjutnya, serta membawa jiwa dan raga anak pada pembelajaran pendidikan jasmani.

\section{Latihan Inti}

Latihan inti diperinci menjadi 5 bagian antara lain: latihan tubuh, latihan keseimbangan, latihan kekuatan dan ketangkasan, latihan jalan dan lari, serta latihan lompat dan loncat. Latihan tubuh dibagi menjadi 4 latihan yaitu latihan penguluran, latihan pelemasan, latihan penguatan, serta latihan pelepasan. Di bawah ini adalah penjelasan cara menyusun latihan serta tujuan latihan.

Pertama, latihan tubuh antara lain: (1) Latihan penguluran, cara menyusun latihan penguluran yaitu: Gerakan disusun dengan mengulur otot-otot dan sendi, gerakan dilakukan berulang-ulang, gerakan dilakukan sedikit demi sedikit untuk menambah rangsangan. Tujuan latihan penguluran yaitu untuk memperpanjang otot-otot dan sendi sehingga memudahkan gerakan senam (fleksibilitas); (2) Latihan pelemasan, cara menyusun latihan pelemasan yaitu: Gerakan disusun dengan melemaskan otot-otot dan sendi, latihan dilakukan dengan melakukan gerakan yang luas dalam segala arah, memungkinkan gerak pada setiap persendian, gerakan dilakukan berulang-ulang dan sedikit demi sedikit untuk menambah rangsangan. Tujuan latihan pelemasan yaitu melemaskan sendi-sendi supaya memudahkan gerak dan memperbesar elastisitas pembungkusan (capsul) dan tali sendi; (3) Latihan penguatan, cara menyusun latihan penguatan yaitu: gerakan disusun dengan menguatkan otot-otot setempat terutama otot yang lemah, misalnya otot perut dan otot pinggang, latihan dengan gerakan-gerakan lambat, latihan dengan menambah beban. Tujuan latihan penguatan yaitu untuk menguatkan otot-otot yang lemah, misal otot perut dan otot pinggang; (4) Latihan pelepasan, cara menyusun latihan pelepasan yaitu: gerakan disusun dengan melepaskan ketegangan-ketegangan otot, gerakan disusun tanpa kekuatan/tidak banyak kerja otot, gerakan disusun dengan memperbaiki koordinasi otot. Tujuan latihan pelepasan yaitu untuk menghilangkan ketegangan otot, memperbaiki koordinasi otot, serta merelaksasikan otot-otot yang tegang.

Kedua, latihan keseimbangan, cara menyusun latihan keseimbangan yaitu: Mempertinggi bidang tumpuan, memperkecil bidang tumpuan, memperpendek jarak antara titik berat badan dengan bidang tumpuan, melakukan latihan dengan memejamkan mata. Tujuan latihan keseimbangan yaitu melatih kontrol gerak tubuh anak, meningkatkan keseimbangan gerak anak, serta melatih pembentukan sikap dan gerak anak.

Ketiga, latihan kekuatan dan ketangkasan, cara menyusun latihan yaitu: gerakan disusun untuk menguatkan, dalam arti untuk melawan beban, gerakan disusun melibatkan kecepatan, misalnya kecepatan bereaksi, kecepatan bergerak, dan kecepatan mengubah arah, gerakan secara mendadak, mislanya gerakan meloncat, menumpu, memukul, dan sebagainya, gerakan yang tahan lama (endurance) atau gerakan yang dilakukan dalam waktu lama. Tujuan latihan kekuatan dan ketangkasan yaitu melatih bergerak secara ekonomis (efisien), melatih mempercepat reaksi gerak, melatih koordinasi otot, serta melatih pembentukan gerak dalam mencapai prestasi.

Keempat, latihan jalan dan lari, cara menyusun latihan, yaitu: gerakan disusun dengan mempertahankan sikap tubuh tetap tegak, gerakan menekankan pada dorongan kaki melalui ujung jari, gerakan disusun untuk meningkatkan daya tahan (endurance). Tujuan latihan jalan dan lari yaitu membenarkan posisi tubuh pada waktu berjalan/berlari, melatih kesadaran arah, serta melatih daya tahan tubuh (endurance).

Kelima, latihan lompat dan loncat, cara menyusun latihan yaitu: Gerakan disusun dengan mencapai ketinggian, gerakan disusun dengan mencapai kejauhan, gerakan disusun dengan memperhatikan posisi kaki dari mulai tolakan, ayunan, dan mendarat. Tujuan latihan 
lompat dan loncat yaitu melatih ketangkasan, melatih daya tahan (endurance), serta mampu melatih otot kaki supaya kuat.

\section{Latihan Pendinginan}

Latihan pendinginan, cara menyusun latihan yaitu: latihan disusun dengan perhatian dan ketenangan, latihan tidak banyak mengeluarkan tenaga, latihan dengan mengatur nafas (menghirup nafas dalam-dalam dan mengeluarkan nafas pelan-pelan). Tujuan latihan yaitu membawa temperatur badan anak kepada temperatur badan yang semula (normal), serta membawa anak ke suasana tenang untuk siap kembali ke dalam kelas.

Anak supaya mampu mencapai keberhasilan dalam proses pembelajaran senam di sekolah, ada beberapa kunci yang sebaiknya dilakukan oleh guru. Price (Lavin, 2008, p.56) menyatakan bahwa ada beberapa kunci antara lain adalah sebagai berikut: (a) Merencanakan bagian-bagian kerja secara menyeluruh, dengan tema dan aktivitas individu yang berdasarkan asosiasi. Aktifitas tersebut disampaikan dengan tingkatan perkembangan di mana siswa tersebut belajar dalam kelas yang sedang diajar, (b) Memelihara harapan yang tinggi secara konsisten terhadap pandangan bahwa siswa mampu dan mengetahui kenyataan bahwa siswa-siswa antusias dan menerima isi senam yang disampaikan kepada siswa dan pada waktu yang sama akan memberi ide kepada siswa-siswa tersebut, (c) Mempersiapkan diri untuk mengulangi dan mengkonsolidasi pekerjaan sebelumnya dengan varian aktivitas yang beragam dan menerapkan alternatif gaya mengajar dan pendekatan-pendekatan untuk memperkaya kualitas tugas yang muncul, (d) Memberikan kegiatan-kegiatan yang berbeda untuk aktivitas di lapangan yang akan membawa interpretasi pelengkap terhadap kemampuan dan tantangan kerja pada fase tingkatan yang berbeda, (e) Tetap bekerja dengan tingkatan yang tinggi, keikutsertaan yang total dan meminimalisasi instruksi yang menandai alur kerja yang dihasilkan, (f) Menciptakan lingkungan dan atmosfir pembelajaran yang positif dengan mengadopsi dan menerapkan rutinitas tugas yang konsisten diperlukan dalam pembelajran dan diaplikasikan, (g) Mengatur dan secara terus-menerus mengukur penampilan yang melawan kriteria yang telah diberikan pada saat proses perencanaan dan untuk mengatur motivasi dan antusias pelajar.
Manfaat Senam Si Buyung

Manfaat Fisik

Senam merupakan aktivitas jasmani yang mampu meningkatkan komponen fisik serta kemampuan gerak anak. Anak yang mengikuti senam akan berkembang daya tahan otot, kekuatan, power, kelentukan, koordinasi, kelincahan, serta keseimbangannya. Kegiatan senam menuntut sistem kerja jentung dan paru, sehingga kegiatan senam sangat mendukung anak dalam perkembangan fisik yang seimbang.

\section{Manfaat Mental dan Sosial}

Senam selain mampu meningkatkan kekuatan fisik anak juga dapat melatih mental dan sosial anak. Senam Si Buyung mampu menuntut anak untuk berfikir sendiri tentang pengembangan keterampilannya. Anak harus mampu menggunakan kemampuan berfikirnya secara kreatif melalui pemecahan masalah-masalah gerak, dengan demikian anak akan berkembang kemampuan mentalnya.

\section{Manfaat Perkembangan Otak}

Senam Si Buyung melalui gerak dan lagu adalah aktivitas yang sangat menyenangkan bagi anak TK, aktivitas gerak dan lagu memberi sumbangan yang besar untuk perkembangan otak anak TK. Kadir (2010, p.110) berpendapat bahwa melalui aktivitas jasmani gerak dan lagu dapat memberikan sumbangan yang besar untuk menyeimbangkan otak anak usia dini, dengan memadukan aktivitas jasmani (olahraga) dan aktivitas mendengarkan musik ataupun menyanyi, dapat membantu membantu perkembangan otak.

\section{Karakteristik Gerak Dasar Senam}

Senam merupakan cabang olahraga yang didirikan oleh keterampilan gerak yang sangat unik. Dilihat dari taksonomi gerak umum, senam secara lengkap diwakili oleh gerak-gerak dasar yang membangun pola gerak yang lengkap, dari mulai pola gerak lokomotor (gerak berpindah tempat), gerak non lokomotor (gerak tidak berpindaah tempat), serta manipulatif (gerak manipulasi objek). Gerakan senam jika ditinjau dari klasifikasi keterampilannya, senam masuk ke dalam keterampilan distrik (berlangsung singkat) sekaligus serial (berkelanjutan) jika sudah berupa rangkaian.

Karakteristik dan struktur gerakan senam merupakan aktivitas fisik yang sangat cocok untuk mengembangkan kualitas motorik 
dan kualitas fisik anak secara sekaligus. Senam mengandung gerakan lokomotor yang dianggap mampu meningkatkan aspek kekuatan, kecepatan, power, daya tahan, kelincahan, serta keseimbangan pada anak. Dihubungkan dengan gerak non lokomotor senam mampu meningkatkan aspek kekuatan, kelentukan, dan keseimbangan statis. Dihubungkan dengan gerak manipulatif senam mampu merangsang kemampuan koordinasi serta pengolahan rangsang pada pusat kesadaran anak.

Senam dapat membantu perkembangan kemampuan gerak lokomotor seperti berjalan, berlari, meloncat, melompat, skipping, berlari cepat, dan berjalan, sedangkan kemampuan gerak nonlokomotor seperti keseimbangan, memutarkan badan, berbalik arah, dan melipat badan. Kegiatan tersebut membantu anak-anak untuk dasar-dasar kecerdasan otak, keseimbangan, dan koordinasi.

Lavin (2008, p.30) menyatakan bahwa senam mampu meningkatkan kemampuan sebagai berikut: (1) Agility: dalam senam anak-anak bisa mengubah tingkat atau arah memutar badan, dan gerak berbalik badan atau cara berjalan dengan menggunakan tubuh; (2) Keseimbangan: beberapa gerakan dalam tari memerlukan sebuah tinkat simertis dan asimetris keseimbangan yang baik; (3) Koordinasi: berjalan dengan cara berbeda dan menggunakan bagian tubuh pada posisi yang berbeda di sekitar tubuh dan ruang.

Keterampilan senam selalu dibangun oleh keterampilan dasar lokomotor, non lokomotor, serta manipulatif (Depdiknas, 2004, p.8), untuk lebih jelasnya uraian dari masingmasing keterampilan adalah sebagai berikut:

\section{Keterampilan Lokomotor}

Sukamti (2007, p.56) mengemukakan keterampilan lokomotor adalah kemampuan tubuh untuk berpindah tempat dari satu tempat ke tempat lainnya atau mengangkat tubuh. Lokomotor diartikan sebagai gerak berpindah tempat seperti jalan, lari, lompat, berjingkat, dan lain-lain. Gerakan tersebut dalam senam sangat penting digunakan, karena hakikatnya hampir seluruh gerakan senam merupakan gerak lokomotor.

\section{Keterampilan Non Lokomotor}

Sukamti (2007, p.58) menyatakan gerak non lokomotor adalah kemampuan gerak tubuh yang dilakukan di tempat, tanpa ada ruang gerak. Keterampilan non lokomotor merupakan gerak yang tidak berpindah tempat, mengandalkan ruas-ruas persendian tubuh untuk membentuk posisi berbeda dengan tetap tinggal di satu titik. Contoh-contoh gerakan non lokomotor yaitu gerakan menghindar, mengayun, peregangan, melipat, dan lain-lain.

\section{Keterampilan Manipulatif}

Samsudin (2008, p.103) menyatakan gerakan manipulasi yaitu gerakan yang melibatkan pemberian gaya kepada objek-objek atau penerimaan gaya dari objek-objek. Bentuk-bentuk keterampilan manipulatif seperti mengayun, menangkap, melempar, mumukul, menendang, dribling, dan sebagainya. Keterampilan manipulatif sering diartikan sebagai kemampuan untuk memanipulasi objek dengan anggota tubuh: tangan, kaki, dan kepala.

\section{Pembelajaran Motorik Kasar pada Anak TK}

Pembelajaran motorik kasar perlu ditekankan dalam aktivitas jasmani di TK. Berfungsinya keterampilan motorik kasar dengan baik dapat mempunyai manfaat untuk keterampilan gerak anak. Samsudin (2008, p.15) mendefinisikan pengayaan motorik kasar adalah aktivitas dengan menggunakan otot-otot besar. Model pembelajaran motorik kasar di TK seperti berjalan di atas papan titian, berjalan dengan berbagai variasi, memanjat, melompat, dan melakukan senam (Depdiknas, 2002, p.20).

Manfaat dan fungsi pembelajaran motorik kasar (Depdiknas, 2002, p.3) adalah sebagai berikut: (1) Manfaat pembelajaran motorik kasar, yaitu: Mampu meningkatkan keterampilan gerak, Mampu memelihara dan meningkatkan kebugaran jasmani, Mampu menanamkan sikap percaya diri, Mampu bekerja sama, Mampu berperilaku disiplin, jujur, dan sportif; (2) Fungsi pembelajaran motorik kasar yaitu, Sebagai alat pemacu pertumbuhan dan perkembangan jasmani, rohani, dan kesehatan anak prasekolah, Sebagai alat untuk membentuk, membangun, dan memperkuat tubuh anak prasekolah, Sebagai alat untuk meningkatkan perkembangan emosional, Sebagai alat untuk meningkatkan perkembangan sosial, Sebagai alat untuk menumbuhkan perasaan senang dan memahami manfaat kesehatan pribadi, Untuk melatih keterampilan dan ketnagkasan gerak juga daya pikir anak prasekolah.

\section{Pola Gerak Anak TK}

Gerak pada anak diawali dengan gerak yang dilakukan tanpa pertimbangan kognitif di 
mana anak hanya melakukan gerak untuk mencapai tujuannya, misalnya gerak mengayunkan tangan untuk memasukkan makanan ke dalam mulut. Sebernarnya anak pada usia dini atau bahkan sangat dini bisa dibantu untuk mempunyai gerak sesuai dengan kemampuan kognitifnya. Piaget, Bruner, dan Gardner (Hughes, 2010, p.224) menyatakan bahwa aktivitas fisik merupakan komponen yang sangat esensial pada pemahaman pengetahuan atau kognitif. Gerak anak secara alamiah dan sensornya merupakan konsep pola gerak pada anak.

Pola gerak pada anak sangat berhubungan pada perkembangan kognitif anak. Piaget (Mu'min dan Yudha, 2000, p.22) mengategorikan perilaku gerak terhadap perkembangan kognitif anak antara lain: (a) sensorimotorik dari lahir sampai dengan 2 tahun, (b) preoperasional dari 2 tahun sampai dengan 8 tahun, (c) konkret operasional dari 8 tahun sampai dengan 11 tahun, (d) formal operasional 11 tahun sampai dengan 12 tahun. Tahapan-tahapan di atas dijabarkan sebagai berikut:

\section{Tahap Sensorimotor}

Tahap sensorimotor menggambarkan berpikir melalui gerak tubuh, kemampuan untuk belajar dan meningkatkan kemampuan intelektual berkembang sebagai suatu hasil dari perilaku gerak dan konsekuensinya. Gerak selalu berhubungan dengan proses berpikir pada tahap sensorimotor, pengetahuan dan berpikir muncul sebagai hasil atau akibat dari perilaku yang terjadi melalui gerak tubuh.

\section{Tahap Preoperasional}

Tahap preoperasional menekankan berupa batasan, anak masih belum memiliki kemampuan untuk berpikir logis atau operasional. Tahap preoperasional dibagi menjadi dua sub bagia antara lain: (a) prekonseptual yaitu anak yang berusia anatara 2 tahun sampai dengan 4 tahun, (b) intuitif yaitu anak yang berusia antara 4 tahun sampai dengan 11 tahun.

\section{Tahapan Konkret Operasional}

Tahapan konkret operasional menekankan bahwa tiap anak akan mencapai tahap konkret operasional dikarenakan anak telah bertambah kemampuannya. Karakteristik umum dari tahapan konkret operasional adalah bertambahnya kemampuan dari variabel dalam situasi problem solving. Kemampuan tersebut dapat dimiliki dampak penting untuk perkembangan motorik pada anak.

\section{Tahapan Formal Operasional}

Tahapan formal operasional menekankan bahwa tahap tersebut merupakan kemampuan untuk mempertimbangkan ide-ide yang tidak didasarkan pada realita. Anak sudah mampu berpikir yang bersifat abstrak.

Teori-teori di atas menunjukkan tahapan anak TK berada pada tahapan preoprasional, tahapan tersebut menunjukkan bahwa anak masih belum memiliki kemampuan untuk berpikir logis atau operasional. Teori preoprasional mendukung senam Si Buyung hanya cocok dilakukan untuk anak TK, karena melihat kemampuan berpikir dari anak TK. Konsep senam Si Buyung merupakan senam bentuk meniru yang gerakannya disusun berdasarkan bentuk cerita dan lagu, berdasarkan bentuk cerita dan lagu mengajak anak untuk meniru gerakan mengikuti isi dari cerita maupun lagu. senam si Buyung melatih kemampuan gerak anak melalui perkembangan kognitif anak.

Piaget (Mu'min dan Yudha, 2000, p.22) menyatakan perkembangan kognitif dan perkembangan gerak secara konstan berinterasi, perkembangan kognitif lebih kuat bergantung pada kemampuan intelektual anak. Tahapan-tahapan seperti di atas selalu dialami anak tanpa pernah dilewati oleh anak. Perkembangan kognitif terjadi melalui proses adaptasi, adaptasi merupakan penyesuaian terhadap tuntutan lingkungan dan intelektual melalui dua hal yaitu asimilasi dan akomodasi. Asimilasi merupakan proses yang anak upayakan untuk menafsirkan pengalaman barunya yang didasarkan pada interpretasinya saat sekarang mengenai dunianya. Akomodasi merupakan aspek kedua dari adaptasi, anak berusaha untuk menyesuaikan keberadaan struktur pikiran dengan sejumlah pengalaman baru. Asimilasi dan akomodasi selalu bekerjasama menjadi dasar perkembangan kognitif dan penekanan akan pentingnya anak menempatkan pada peranan lingkungan dalam perkembangan manusia.

\section{Karakteristik Anak TK}

Anak TK berada dalam masa keemasan di sepanjang rentang usia perkembangan manusia. Montessori (Sujiono, 2011, p.54) menjelaskan masa anak usia dini merupakan periode sensitif (sensitive periods), selama masa ini anak secara khusus mudah menerima stimulusstimulus dari lingkungannya. Masa anak siap melakukan berbagai kegiatan dalam rangka memahami dan menguasai lingkungannya. Usia 
keemasan pada anak merupakan masa di mana anak mulai peka untuk menerima berbagai stimulasi dan berbagai upaya pendidikan dari lingkungannya baik disengaja maupun tidak disengaja. Masa peka inilah terjadi pematangan fungsi-fungsi fisik dan psikis sehingga anak siap merespon dan mewujudkan semua tugastugas perkembangan yang diharapkan muncul pada pola perilakunya sehari-hari.

Berdasarkan teori perkembangan anak seperti di atas diyakini bahwa setiap anak lahir dengan memiliki banyak bakat. Bakat tersebut bersifat potensial dan ibaratnya belum terlihat pada anak, untuk itulah anak perlu diberikan pendidikan yang sesuai dengan perkembangannya dengan cara memperkaya lingkungan bermainnya. Orang dewasa perlu memberi peluang kepada anak untuk menyatakan diri, berekspresi, berkreasi, dan menggali sumber-sumber terunggul yang sembunyi dalam diri anak. Pendidikan anak TK haruslah berorientasi pada pendekatan berpusat pada anak dan perlahanlahan menyeimbangkan dominasi pendekatan lama yang lebih berpusat pada guru.

Hakikatnya anak adalah makhluk individu yang membangun sendiri pengetahuannya. Anak lahir dengan membawa sejumlah potensi yang siap untuk ditumbuhkembangkan asalkan lingkungan menyiapkan situasi dan kondisi yang dapat merangsang kemunculan dari potensi yang tersembunyi. Berdasarkan tinjauan aspek pedagogis, masa usia dini merupakan masa pondasi awal bagi pertumbuhan dan perkembangan selanjutnya. Masa kanak-kanak yang bahagia merupakan dasar bagi keberhasilan di masa datang dan sebaliknya, agar pertumbuhan dan perkembangan tercapai secara optimal, maka dibutuhkan situasi dan kondisi yang kondusif pada saat memberikan stimulasi dan upaya pendidikan yang sesuai dengan kebutuhan dan minat anak.

Secara teoritis berdasarkan aspek perkembangannya, seorang anak dapat belajar dengan sebaik-baiknya apabila kebutuhan fisiknya dipenuhi dan anak merasa aman dan nyaman secara psikologis, hal lain yang perlu diperhatikan adalah bahwa anak membangun pengetahuannya sendiri, anak belajar melalui interaksi sosial dengan orang dewasa dan anak-anak lainnya, anak belajar melalui bermain serta terdapat variasi individual dalam perkembangan dan belajar.

Masa kanak-kanak merupakan masa untuk mengeksplorasi proses berpikir, Santrock (2007, p.295) menyatakan tipe-tipe proses ber- pikir: berpikir kritis, berpikir ilmiah, dan penyelesaian masalah. Pernyataan tersebut dapat dijadikan acuan untuk melatih anak dalam berpikir. Program-program pembelajaran di sekolah harusnya disusun supaya mampu melatih anak dalam berpikir, misalnya dalam pemecahan masalah. Anak banyak menghadapi masalah di sekolah maupun di luar sekolah. Pemecahan masalah seperti usaha menemukan cara yang tepat untuk mencapai tujuan perlu diajarkan pada anak supaya anak mampu mengatasi masalah yang dihadapinya.

Masa kanak-kanak merupakan masa di mana anak susah untuk diatur, susah diatur yaitu anak melakukan apapun dengan semaunya sendiri. Masa anak tidak berakhir begitu saja melainkan diawali dengan masa yang menyulitkan yaitu umumnya muncul sekitar anak umur tiga tahun. Anak yang setiap hari selalu menurut dan patuh kepada orang tuanya, dapat berubah menjadi anak yang nakal yang tidak nurut apa kata orang tuanya. Anak menjadi keras kepala, pembantah, penentang, dekil, dan lain sebagainya. Anak mengalami perubahan tingkah laku dalam menemukan jati dirinya. Anak menyadari bahwa anak sama seperti orang lain, mempunyai kebebasan berbuat, kebebasan berkehendak, kebebasan melakukan apa yang diinginkan seperti ayah maupun ibunya.

Anak mulai menyadari jati dirinya, anak mulai menemukan kepribadiannya. Keinginan anak untuk dapat berdiri sendiri sebagai manusia yang hidup dalam masyarakat. Anak adalah makhluk individu yang sekaligus adalah makhluk masyarakat. Anak dapat diperintah tetapi juga dapat memerintah, anak mampu diminta untuk tunduk tetapi anak juga mampu meminta untuk tidak tunduk. Sifat anak mulai dari dapat diperintah dan mampu memerintah. Soejanto (2005, p.40) menyatakan beberapa sifat-sifat pada anak adalah sebagai berikut: (a) Egocentris, artinya segala sesuatu ingin dipusatkan pada anak, dan demi kepentingan anak. Anak menuntut agar seluruh lingkungan berada di bawah kekuasaannya, (b) Selalu menentang, membantah, segala permintaan, suruhan, larangan, anjuran, keharusan, dan sebagainya yang datang dari siapa juga, (c) Anak selalu berusaha menarik perhatian. Semua orang yang ada di sekitarnya harus memperhatikannya, (d) Anak selalu meminta untuk dihargai, dipuji, dan tidak mau dicela dipersalahkan atau dianggap tidak mampu, (e) Anak selalu menuntut adanya kebebasan, (f) Keberaniannya bertambah dan rasa takutnya mulai berkurang. 
Berdasarkan pendapat di atas dapat disimpulkan bahwa sifat anak pada masa pertumbuhan untuk mencari jati dirinya dapat melakukan banyak kesalahan. Pada masa tersebut seharusnya orang tua mampu melakukan pendekatan pada anak melalui media-media yang mendidik, sehingga anak tidak salah dalam masa pertumbuhan untuk mencari jati dirinya. Orang tua seharusnya tidak membatasi diri anak untuk berkembang, peran orang tua seharusnya mengawasi dan mengarahkan pada diri anak. Sikap orang tua seperti banyak memerintah, melarang, menyuruh, dan campur tangan dalam apa yang dilakukan anak sebaiknya tidak ditekankan pada anak.

Anak dalam mencari jati dirinya biasanya menyukai sanjungan dari orang tua. Orang tua sebaiknya banyak memberikan reward kepada anak jika anak melakukan keberhasilan dalam belajar, misalnya saja pada waktu anak mampu menghitung atau melafalkan hurufhuruf dengan baik dan benar. Orang tua memberikan pujian pada anak sehingga anak akan termotivasi untuk giat belajar. Anak jika melakukan kesalahan sebaiknya orang tua memberikan teguran dengan sikap yang halus, menggunakan kata-kata yang enak supaya anak mampu memahami dan mengerti jika anak telah melakukan kesalahan. Adanya sikap memahami anak sangat penting supaya anak mampu di arahkan dengan baik.

Soejanto (2005, p.41) menyatakan bahwa, "Masa Trotz adalah merupakan masa peralihan, dari masa kanak-kanak ke masa anak. Masa Trotz berlaku satu tahun." Masa Trotz anak harus diberikan pelayanan dari orang tua dengan baik, jika pada masa peralihan anak mendapatkan pelayanan yang keliru maka anak akan benar-benar tumbuh menjadi anak yang sukar dikendalikan. Diharapkan pada masa peralihan anak harus mendapatkan pendidikan dengan mengikuti proses perkembangannya, seperti anak masuk mengikuti pendidikan formal/nonformal misalnya anak masuk untuk mendapatkan pembelajaran di PAUD, TK, atau TPA. Adanya pendidikan mampu menunjang anak ke arah yang lebih baik.

\section{Pertumbuhan dan Perkembangan Anak TK}

Pertumbuhan dan perkembangan pada anak TK banyak dipengaruhi oleh faktor-faktor, seperti faktor gizi, lingkungan serta genitika. Faktor-faktor tersebut mempengaruhi pertumbuhan dan perkembangan anak menuju ke arah berikutnya. Cholik (Samsudin, 2008, p.6) me- nyatakan pertumbuhan merupakan perubahan dari ukuran bentuk tubuh, sedangkan Cratty (Samsudin, 2008, p.6) menyatakan perkembangan berkaitan dengan kematangan mekanisme otot, syaraf, serta keterampilan motorik. Tumbuh kembang anak sangat perlu diperhatikan, supaya anak mampu mendapatkan bentuk dan fungsi tubuh secara baik. Memberikan stimulus-stimulus secara optimal mampu mempengaruhi tumbuh kembang anak. Pemberian asupan gizi serta pembelajaran gerak secara baik dapat menunjang tumbuh kembang anak.

Davies (2003, p.1) menyatakan bahwa gerak memberikan peranan yang penting dalam pertumbuhan, perkembangan dan pendidikan anak. Ada tiga kategori yang penting dan saling berhubungan dalam menyusun pembelajaran gerak antara lain: (a) dinamis yang menghubungkan bagaimana instrumen bergerak, (b) space yang mengacu pada cara-cara yang ada dalam tubuh dan menggunakan ruang atau space, dan (c) hubungan (relationship) yang mengidentifikasi cara-cara di mana tubuh bergerak dan berhubungan dengan manusia dan objek.

Berdasarkan pendapat seperti di atas bahwa anak sangat memerlukan banyak gerak untuk membantu pertumbuhan dan perkembangan, dalam menyusun pembelajaran gerak pada anak harus disusun secara bertahap. Gerak di mulai dari yang dinamis dengan menghubungkan berbagai instrumen gerak hingga gerak yang menghubungkan dengan manusia/objek di sekitarnya, dengan demikian anak mampu melatih geraknya secara efektif untuk mengetahui ruang di sekitarnya.

Ketertarikan bahwa anak-anak menampilkan gerak terbagi dalam empat katergori yang saling berkaitan. Davies (2003, p.54) membagi kategori tersebut menjadi empat antara lain: (a) Menghubungkan tubuh anak-anak dengan lingkungan yang stabil dengan aktivitas seperti berjalan merangkak, memanjat, berayun, dan keseimbangan, (b) Mengetes pribadi anakanak akan kekuatan dan gerak akrobatik dan atletik seperti menggulingkan badan (roll), jatuh berguling-guling (tumble), melompat (leap), dan mendarat (land), (c) Menguji ketangkasan siswa dengan memberikan dan bermain dengan benda seperti rattle, bola, simpai, tali, tongkat, pemukul, dan batu, (d) Menikmati gerak untuk kepentingan pribadi siswa tersebut dalam kegiatan berbalik, berjalan mengelilingi sesuatu, berputar-putar, menyambar yang muncul secara spontan dari waktu ke waktu. 
Kategori-kategori seperti di atas merupakan bentuk pembelajaran gerak untuk melatih kemampuan gerak anak. Anak semakin menikmati pembelajaran yang menyenangkan, secara tidak sadar anak menambah kemampuan gerakannya dengan banyak melakukan aktivitas bermain seperti merangkak, berayun, melompat, serta berguling-guling. Anak dengan banyak aktivitas berbagai macam gerak mampu menstimulasi pertumbuhan fisik maupun mentalnya, dengan demikian sumbangsi belajar gerak pada anak mempunyai banyak manfaat terhadap perkembangan diri anak.

Seefeldt (2008, p.63) menyatakan bahwa perkembangan anak TK meliputi perkembangan fisik, emosi, bahasa, kognitif, dan sosial. Dalam perkembangan anak upaya mendidik atau membimbing anak supaya anak dapat mengembangkan potensi dirinya seoptimal mungkin sangat dibutuhkan. Guru dan orang tua harus berperan aktif dalam perkembangan anak, mengajarkan anak ke arah positif sangat penting seperti mengenalkan anak untuk berolahraga, menanamkan sikap kejujuran, berbicara sopan santun, mengajarkan untuk rajin membaca, serta mengajarkan anak untuk saling tolong menolong. Pembelajaran tersebut mampu mendorong anak untuk tumbuh dan berkembang dengan baik. Masa-masa anak merupakan masa emas, masa di mana anak menentukan pertumbuhan dan perkembangan selanjutnya, jika pada masa emas anak sudah mendapatkan stimulus yang positif maka anak selanjutnya akan tumbuh dan berkembang secara optimal.

Yusuf (2004, p.17) menyatakan prinsip-prinsip dalam perkembangan anak antara lain: (a) Perkembangan merupakan proses yang tidak pernah berhenti, (b) Semua aspek perkembangan saling mempengaruhi, (c) Perkembangan mengikuti pola atau arah tertentu, (d) Perkembangan terjadi pada tempo yang berlainan, (e) Setiap fase perkembangan mempunyai ciri khas, (f) Setiap individu yang normal akan mengalami tahapan/fase perkembangan.

Berdasarkan prinsip perkembangan di atas setiap anak mengalami berkembangan secara terus menerus. Setiap aspek perkembangan baik fisik dan mental saling mempengaruhi. Perkembangan terjadi secara teratur mengikuti pola tertentu, setiap tahap perkembangan merupakan hasil perkembangan dari tahap sebelumnya. Perkembangan fisik dan mental anak mencapai kematangannya terjadi pada waktu yang berbeda-beda. Anak dalam perkembangan fisik dan mental ada yang cepat maupun lambat dise- suaikan dengan genetik maupun stimulus yang diberikan pada anak.

Stimulus pada anak melalui aktivitas gerak sangat penting dalam membantu mengoptimalkan tumbuh kembang anak. Adanya aktivitas gerak dalam media pembelajaran sangat diharapkan dalam tumbuh kembang anak. Pembelajaran melalui aktivitas jasmani di sekolah sangat penting, pembelajaran jasmani di TK sebaiknya dilakukan melalui aktivitas-aktivitas seperti menari, permainan, olahraga, dan senam. Aktivitas-aktivitas tersebut masuk ke dalam wilayah pendidikan jasmani. Pembelajaran aktivitas jasmani melalui senam Si Buyung di TK dapat mempengaruhi pertumbuhan dan perkembangan anak. Belajar melalui aktivitas jasmani akan membantu mengoptimalkan empat ranah dalam pendidikan di TK yaitu: ranah kognitif, afektif, dan psikomotor.

Senam Si Buyung mampu mengoptimalkan berbagai ranah yang ada dalam pendidikan, di dalam senam Si Buyung bentuk cerita terdapat kemampuan untuk melatih ranah tersebut. Ranah kognitif berhubungan dengan kemampuan berpikir, senam Si Buyung bentuk cerita mengajak anak untuk berpikir dan membayangkan dalam alur cerita. Ranah afektif berhubungan dengan sikap dan perasaan senang, senam Si Buyung memerlukan kedisiplinan dalam mengikuti senam dari mulai berbaris yang rapi hingga mendengarkan instruksi guru. Ranah yang terakhir yaitu ranah psikomotor berkaitan dengan kebugaran jasmani serta melatih kemampuan gerak pada anak.

Pembelajaran gerak (motorik) terdiri atas beberapa tingkatan, Schmidt (2005, p.402) menjelaskan tiga tingkatan dalam pembelajaran motorik antara lain sebagai berikut: (a) Tingkatan pertama yaitu tingkat kognitif. Tingkat kognitif anak mampu memahami gerak yang harus dikeluarkan dengan strategi yang tepat untuk mendapatkan gerak yang diinginkan. Guru memberikan kegiatan imajinatif, instruksi, model, timbal balik yang membangun, dan bermacam-macam teknik pelatihan yang mendukung lainnya, (b) Tingkat kedua adalah tingkat asosiatif di mana anak menghasilkan cara yang paling efektif dalam menyelesaikan tugas atau kegiatan untuk menampilkan kemampuan anak. Gerak yang dihasilkan anak lebih konsisten dan lebih berfokus pada bagaimana melakukan gerakan, dalam tingkat asosiatif diperlukan waktu yang cukup lama karena anak akan menghasilkan penampilan yang lebih efektif, (c) Tingkatan ketiga yaitu tingkatan otonomi (independen). 
Anak menghasilkan gerak secara otomatis dengan aktivitas yang berkelanjutan, pada tingkatan otonomi anak memerlukan pemahaman yang profesional, sebagai contoh pemain piano tidak perlu melihat pianonya ketika memainkan alat musik tersebut.

\section{Metode}

Penelitian yang dilakukan menggunakan metode penelitian dan pengembangan atau sering disebut (research and development). Borg dan Gall (1983, p.772) menyatakan penelitian dan pengembangan merupakan metode penelitian untuk menghasilkan produk-produk pendidikan, baik produk yang berupa objek material seperti buku teks, dan film pengajaran. Produk yang berupa proses dan prosedur yang ditemukan seperti metode mengajar atau metode mengorganisir pengajaran. Penelitian pengembangan dilakukan untuk menghasilkan sebuah buku panduan dan CD senam Si Buyung sebagai pembelajaran motorik kasar pada siswa taman kanak-kanak. Pengembangan dilakukan berdasarkan kajian terhadap kurikulum yang ada di TK. Pemilihan bentuk lagu dan cerita dalam senam Si Buyung berdasarkan pada tahaptahap perkembangan dan karakteristik anak, sehingga model yang dihasilkan sesuai bagi anak.

Prosedur pengembangan dalam penelitian sesuai dengan langkah-langkah penelitian pengembangan menurut Borg dan Gall. Menurut Borg dan Gall (1983, p.775) dalam melakukan penelitian pengembangan ada beberapa langkah yang harus ditempuh, langkah-langkah yang harus ditempuh tersebut, dapat digambarkan sebagai berikut: (1) pengumpulan hasil riset dan informasi, (2) perencanaan, (3) pengembangan produk awal, (4) uji coba awal, (5) revisi untuk menyusun produk utama, (6) uji coba lapangan utama, (7) revisi untuk menyusun produk operasional, (8) uji coba produk operasional, (9) revisi produk final, dan (10) diseminasi dan implementasi produk hasil pengembangan. Langkah-langkah tersebut diadaptasi menjadi tujuh rancangan prosedur penelitian pengembangan berikut ini: (1) Pengumpulan informasi di lapangan, (2) Melakukan analisis terhadap informasi yang telah dikumpulkan, (3) Pengembangan produk awal (draf model), (4) Validasi ahli dan revisi, (5) Uji coba lapangan skala kecil dan revisi, (6) Uji coba lapangan skala besar dan revisi, (7)Pembuatan produk final.

\section{Hasil Penelitian Dan Pembahasan}

Hasil penilaian para ahli materi di lapangan terhadap model senam Si Buyung meliputi: (1) observasi senam Si Buyung, (2) observasi keefektifan model senam Si Buyung, dan (3) observasi terhadap guru pelaku uji coba. Data-data tersebut dipaparkan berikut ini.

Tabel 1. Data Hasil Observasi Model Senam Si Buyung

\begin{tabular}{|c|c|c|c|c|c|c|c|c|c|}
\hline \multirow{2}{*}{$\begin{array}{c}\text { Ahli } \\
\text { Materi }\end{array}$} & \multicolumn{8}{|c|}{ Item Observasi } & \multirow{2}{*}{$\begin{array}{l}\text { Total } \\
\text { Nilai }\end{array}$} \\
\hline & $\mathbf{1}$ & 2 & 3 & 4 & 5 & 6 & 7 & 8 & \\
\hline $\begin{array}{c}\text { Pakar } \\
\text { Senam (1) }\end{array}$ & 1 & 1 & 1 & 1 & 1 & 1 & 1 & 1 & 8 \\
\hline $\begin{array}{c}\text { Pakar } \\
\text { Senam (2) }\end{array}$ & 1 & 1 & 1 & 1 & 1 & 1 & 1 & 1 & 8 \\
\hline $\begin{array}{c}\text { Guru TK } \\
\text { (1) }\end{array}$ & 1 & 1 & 1 & 1 & 1 & 1 & 1 & 1 & 8 \\
\hline $\begin{array}{c}\text { Guru TK } \\
\text { (2) }\end{array}$ & 1 & 1 & 1 & 1 & 1 & 1 & 1 & 1 & 8 \\
\hline $\begin{array}{c}\text { Ahli } \\
\text { Media }\end{array}$ & 1 & 1 & 1 & 1 & 1 & 1 & 1 & 1 & 8 \\
\hline
\end{tabular}

Berdasarkan hasil tabel penilaian observasi model senam Si Buyung dimasukkan ke dalam norma kategori. Berikut penyajian norma kategori pada Tabel 2:

Tabel 2. Penghitungan Normatif Kategorisasi

\begin{tabular}{ccc}
\hline Formula & Batasan & Kategori \\
\hline$X<(\mu-1,0 \sigma)$ & $X<2,67$ & Kurang \\
$(\mu-1,0 \sigma) \leq X<(\mu+1,0 \sigma)$ & $2,67 \leq X<5,33$ & Cukup \\
$(\mu+1,0 \sigma) \leq X$ & $5,33 \leq X$ & Baik \\
\hline
\end{tabular}

Keterangan: $X=$ jumlah skor subjek; $\mu=$ mean ideal $=1 / 2[(8 \times 1)+(8 \times 0)]=4 ; \sigma=$ standar devisiasi ideal $=1 / 6[(8 \times 1)-(8 \times 0)]=1,33$.

Mengacu pada kategorisasi tersebut maka hasil penilaian observasi model senam $\mathrm{Si}$ Buyung dari para ahli materi dapat diketahui dan disajikan ke dalam Tabel 3 berikut.

Tabel 3. Distribusi Frekuensi

\begin{tabular}{cccr}
\hline Interval & Kategori & Frek & Persen \\
\hline $\mathrm{X}<2,67$ & Kurang & 0 & $0,00 \%$ \\
$2,67 \leq \mathrm{X}<5,33$ & Cukup & 0 & $0,00 \%$ \\
$5,33 \leq \mathrm{X}$ & Baik & 5 & $100,00 \%$ \\
Jumlah & & 5 & $100,00 \%$ \\
\hline
\end{tabular}

Tabel di atas menunjukkan penilaian observasi ahli materi terhadap model senam $\mathrm{Si}$ Buyung sebagai pembelajaran motorik kasar pada siswa TK tidak ada subjek $(0 \%)$ yang kategori kurang, tidak ada subjek $(0 \%)$ yang kategori cukup, dan lima responden $(100,00 \%)$ kategori baik. Total nilai para ahli semuanya sama yaitu sebesar 8 terletak pada interval 5,33 
$\leq \mathrm{X}$, maka penilaian para ahli materi terhadap hasil observasi model senam Si Buyung sebagai pembelajaran motorik kasar pada siswa TK mengkategorikan baik.

Tabel 4. Data Hasil Observasi Keefektifan Model Senam Si Buyung

\begin{tabular}{cccccccccc}
\hline Ahli & \multicolumn{1}{c}{ Item Observasi } & Total \\
\cline { 2 - 7 } Materi & $\mathbf{1}$ & $\mathbf{2}$ & $\mathbf{3}$ & $\mathbf{4}$ & $\mathbf{5}$ & $\mathbf{6}$ & $\mathbf{7}$ & $\mathbf{8}$ & Nilai \\
\hline $\begin{array}{c}\text { Pakar } \\
\text { Senam (1) }\end{array}$ & 1 & 1 & 1 & 1 & 1 & 1 & 1 & 1 & 8 \\
$\quad$ Pakar & 1 & 1 & 1 & 1 & 1 & & & & \\
$\begin{array}{c}\text { Senam (2) } \\
\text { Guru TK }\end{array}$ & 1 & 1 & 1 & 1 & 1 & 1 & 1 & 1 & 8 \\
$\quad(1)$ & 1 & 1 & 1 & 1 & 1 & 1 & 1 & 1 & 8 \\
$\begin{array}{c}\text { Guru TK } \\
(2)\end{array}$ & 1 & 1 & 1 & 1 & 1 & 1 & 1 & 1 & 8 \\
\hline
\end{tabular}

Berdasarkan hasil tabel penilaian observasi kefektifan model senam Si Buyung dimasukkan ke dalam norma kategori. Berikut penyajian norma kategori pada Tabel 5:

Tabel 5. Penghitungan Normatif Kategorisasi

\begin{tabular}{ccc}
\hline Formula & Batasan & Kategori \\
\hline$X<(\mu-1,0 \sigma)$ & $X<2,67$ & Kurang \\
$(\mu-1,0 \sigma) \leq X<(\mu+1,0 \sigma)$ & $2,67 \leq X<5,33$ & Cukup \\
$(\mu+1,0 \sigma) \leq X$ & $5,33 \leq X$ & Baik \\
\hline
\end{tabular}

Keterangan: $X=$ jumlah skor subjek; $\mu=$ rerata ideal $=1 / 2[(8 \times 1)+(8 \times 0)]=4 ; \sigma=$ simpangan baku ideal $=1 / 6[(8 \times 1)-(8 \times 0)]=1,33$.

Mengacu pada kategorisasi tersebut maka hasil penilaian observasi keefektifan model senam Si Buyung dari para ahli materi dapat diketahui dan disajikan ke dalam Tabel 6 berikut.

\begin{tabular}{cccr}
\multicolumn{4}{c}{ Tabel 6 Distribusi Frekuensi } \\
\hline Interval & Kategori & Frek & Persen \\
\hline $\mathrm{X}<2,67$ & Kurang & 0 & $0,00 \%$ \\
$2,67 \leq \mathrm{X}<5,33$ & Cukup & 0 & $0,00 \%$ \\
$5,33 \leq \mathrm{X}$ & Baik & 4 & $100,00 \%$ \\
Jumlah & & 4 & $100,00 \%$ \\
\hline
\end{tabular}

Tabel di atas menunjukkan penilaian ahli materi terhadap senam Si Buyung sebagai pembelajaran motorik kasar pada siswa TK tidak ada subjek $(0 \%)$ yang kategori kurang, tidak ada subjek $(0 \%)$ yang kategori cukup, dan empat responden $(100,00 \%)$ kategori baik. Total nilai para ahli semuanya sama yaitu sebesar 8 terletak pada interval $5,33 \leq \mathrm{X}$, maka penilaian para ahli materi terhadap hasil observasi keefektifan model senam Si Buyung sebagai pembelajaran motorik kasar pada siswa TK mengkategorikan baik.
Tabel 7 Data Observasi

Terhadap Guru Pelaku Uji Coba

\begin{tabular}{ccccccc}
\hline \multirow{2}{*}{ Ahli Materi } & \multicolumn{4}{c}{ Item Observasi } & \multirow{2}{*}{ Total Nilai } \\
\cline { 2 - 6 } & $\mathbf{1}$ & $\mathbf{2}$ & $\mathbf{3}$ & $\mathbf{4}$ & $\mathbf{5}$ & \\
\hline Pakar Senam (1) & 1 & 1 & 1 & 1 & 1 & 5 \\
Pakar Senam (2) & 1 & 1 & 1 & 1 & 1 & 5 \\
Guru TK (1) & 1 & 1 & 1 & 1 & 1 & 5 \\
Guru TK (2) & 1 & 1 & 1 & 1 & 1 & 5 \\
\hline
\end{tabular}

Berdasarkan hasil tabel penilaian observasi terhadap guru yang melakukan uji coba model senam Si Buyung dimasukkan ke dalam norma kategori. Berikut penyajian norma kategori pada Tabel 8:

Tabel 8 Penghitungan Normatif Kategorisasi

\begin{tabular}{ccc}
\hline Formula & Batasan & Kategori \\
\hline $\mathrm{X}<(\mu-1,0 \sigma)$ & $\mathrm{X}<1,67$ & Kurang \\
$(\mu-1,0 \sigma) \leq \mathrm{X}<(\mu+1,0 \sigma)$ & $1,67 \leq \mathrm{X}<3,33$ & Cukup \\
$(\mu+1,0 \sigma) \leq \mathrm{X}$ & $3,33 \leq \mathrm{X}$ & Baik \\
\hline
\end{tabular}

Keterangan: $\mathrm{X}=$ jumlah skor subjek; $\mu=$ mean ideal $=1 / 2[(5 \times 1)+(5 \times 0)]=2,5 ; \sigma=$ standar devisiasi ideal $=1 / 6[(5 \times 1)-(5 \times 0)]=0,83$.

Mengacu pada kategorisasi tersebut maka hasil observasi terhadap guru pelaku uji coba model senam Si Buyung sebagai pembelajaran motorik kasar pada siswa TK dari para ahli materi dapat diketahui dan disajikan ke dalam tabel 9 berikut.

Tabel 9. Distribusi Frekuensi

\begin{tabular}{cccr}
\hline Interval & Kategori & Frek & Persen \\
\hline $\mathrm{X}<1,67$ & Kurang & 0 & $0,00 \%$ \\
$1,67 \leq \mathrm{X}<3,33$ & Cukup & 0 & $0,00 \%$ \\
$3,33 \leq \mathrm{X}$ & Baik & 4 & $100,00 \%$ \\
Jumlah & & 4 & $100,00 \%$ \\
\hline
\end{tabular}

Tabel di atas menunjukkan penilaian ahli materi terhadap senam Si Buyung sebagai pembelajaran motorik kasar pada siswa TK tidak ada subjek $(0 \%)$ yang kategori kurang, tidak ada subjek $(0 \%)$ yang kategori cukup, dan empat responden $(100,00 \%)$ kategori baik. Total nilai para ahli semuanya sama yaitu sebesar 5 terletak pada interval $3,33 \leq \mathrm{X}$, maka penilaian para ahli materi terhadap hasil observasi guru yang melakukan uji coba model senam Si Buyung sebagai pembelajaran motorik kasar pada siswa TK mengkategorikan baik.

\section{Kesimpulan}

Berdasarkan hasil penelitian yang telah diuraikan pada bagian pembahasan, maka dapat diambil kesimpulan bahwa gerakan yang dirangkai pada senam Si Buyung sesuai dengan karakteristik siswa TK. Gerakan senam si Bu- 
yung disesuaikan dengan standar kompetensi dan kompetensi dasar yang termuat dalam kurikulum, disesuaikan dengan pertumbuhan dan perkembangan anak TK, serta disesuaikan dengan tingkat keamanan pelaksanaan kegiatan di sekolah. Model senam Si Buyung yang dibuat juga layak digunakan untuk pembelajaran mo-torik kasar pada siswa TK. Uji kelayakan dila-kukan berdasarkan penilaian para ahli materi, penilaian ahli materi menunjukkan bahwa senam Si Buyung yang disusun layak untuk digunakan sebagai pembelajaran motorik kasar di TK. Produk dari penelitian pengembangan yaitu buku RKH (rencana kegiatan harian) dan $\mathrm{CD}$ model senam Si Buyung untuk pembelajaran motorik kasar pada siswa TK.

\section{Daftar Pustaka}

Borg, Walter R. \& Gall. M. D. (1983). Educational research. (an introduction) $4^{\text {th }}$ edition. New York \& London: Longman.

Davies, Mollie. (2003). Movement and dance in the early years. London: Sage Publications Companion.

Depdiknas. (2002). Model pengembangan motorik anak prasekolah. Jakarta: Depdiknas.

Depdiknas. (2004). Instrumen pemanduan bakat senam. Jakarta: Depdiknas.

Hughes, Fergus P. (2010). Children, play, and development. USA: SAGE Publications.

Kadir, Abdul. (2010). Misteri otak kiri manusia. Yogyakarta: Diva Press.

Lavin, Jim. (2008). Creattive approaches to physical education: helping children to achieve their true potential. New York: Routledge.

Ma'mun, Amung \& Saputra, Yudha M. (2000). Perkembangan gerak dan belajar gerak. Jakarta: Depdikbud.

Mawarti, Sri., Sukamti, Endang Rini., \& Prasetyo, Yudik. (2010). Pembuatan paket senam Si Buyung untuk guruguru TK. Yogyakarta: UNY.

Samsudin. (2008). Pembelajaran motorik di taman kanak-kanak. Jakarta: Litera.

Santrock, John W. (2007). Perkembangan anak. (Terjemahan Mila Rachmawati \& Anna Kuswanti). Jakarta: Erlangga. (Buku asli diterbitkan tahun 2007)

Schmidt, Richard A. (2005). Motor control and learning. USA: Human Kinetics.

Seefeldt, Carol. (2008). Pendidikan anak usia dini. (Terjemahan Pius Nasar). Jakarta: PT. Indeks. (Buku asli diterbitkan tahun 2006)

Soejanto, Agoes. (2005). Psikologi perkembangan. Jakarta: PT. Rineka Cipta.

Sujiono, Yuliani Nurani. (2011). Konsep dasar pendidikan anak usia dini. Jakarta: PT. Indeks.

Sukamti, Endang Rini. (2007). Diktat perkembangan motorik. Yogyakarta: UNY.

Yusuf, Syamsu, L. N. (2004). Psikologi perkembangan anak dan remaja. Bandung: PT. Remaja Rosdakarya. 